TOMISLAV JOSIP MLINARIĆ, Ph.D. ${ }^{1}$

E-mail: tmlinaric@fpz.hr

BOBAN ĐORĐEVIĆ, Ph.D. student ${ }^{2}$

E-mail: bbn.djordjevic@gmail.com

EVELIN KRMAC, Ph.D. ${ }^{2}$

(Corresponding author)

E-mail: evelin.krmac@fpp.uni-lj.si

${ }^{1}$ Faculty of Transport and Traffic Sciences,

University of Zagreb

Vukelićeva 4, 10000 Zagreb, Croatia

2 Faculty of Maritime Studies and Transport,

University of Ljubljana

Pot pomorščakov 4, SI-6320 Portorož, Slovenia
Intelligent Transport Systems (ITS)

Preliminary Communication

Submitted: 16 Oct. 2017

Accepted: 12 Apr. 2018

\title{
EVALUATION FRAMEWORK FOR KEY PERFORMANCE INDICATORS OF RAILWAY ITS
}

\begin{abstract}
The aim of this study is to develop a framework for investigating a comprehensive set of Key Performance Indicators (KPIs) for the assessment of railway Intelligent Transportation Systems (ITS). The framework is established through four main steps: 1) development of a comprehensive set of KPIs for railway ITS; 2) validation of developed KPIs and collection of judgments from experts through a Delphi questionnaire; 3) evaluation of KPls weights for assessing railway ITS with the Group Analytical Hierarchy Process (GAHP); and 4) presentation of a SWOT analysis for the developed KPIs by the authors. The results of the framework are presented as a set of 25 indicators for evaluation of railway ITS and their impacts. The framework could be helpful for selecting KPIs of ITS in another mode of transportation. Monitoring of the contributions of ITS towards sustainable railway can be achieved by a developed set of indicators which are classified in accordance with sustainable dimensions.
\end{abstract}

\section{KEY WORDS}

framework; railway; Intelligent Transportation Systems; group decision making; identification; evaluation; sustainable railway;

\section{INTRODUCTION}

In the context of rail transport, railway ITS are systems working in a synergy of sensors, communications, computing, and intelligent control used for various aspects of rail system management and control, i.e., customer service, planning and scheduling, dispatch, block control, interlock, and speed control. In terms of rail transport, an example of such a complex system is the train control system [1]. Railway ITS aims at meeting important technological and economic objectives, such as increased capacity and asset utilization, improved reliability and safety, higher customer service levels, better energy efficiency and fewer emissions, and increased economic viability and profits [2].
Summarizing the effects of ITS can be very useful for stakeholders of all kinds. The effects of ITS can be observed as a decision support tool both in making the right decisions in terms of ITS deployment or development and in recognizing the areas of improvement or evaluation of ITS. On the other hand, lack of easy and efficient access to ITS impacts can be a crucial factor slowing ITS deployment and reducing willingness to invest in ITS. However, most guidelines do not detail how the impacts should be measured or valued, with many benefits being inherently difficult to measure or even define in an agreed manner [3]. ITS impacts could be summarized through a set of comprehensive KPIs. KPIs are indicators used to measure, track, and report the progress towards delivery on effects identified as critical to the success of transportation organization's goals and objectives. KPIs provide a summary of information about the characteristics of ITS and understanding which ITS performance effects are achieved. The main purpose of KPIs should be directed at supporting decisions and considering aspects that can be managed. Without specific indicators which represent ITS effects, it is difficult to determine whether transportation performances are improved or what needs to be done to make them better. Since ITS are complex systems, a set of KPIs is necessary to evaluate them. Following the European Union (EU) goals, the ITS action plan [4], and ITS Directive 2010/40/EU [5], certain steps have been made for developing and summarizing a comprehensive set of KPIs of ITS for road transport. Unfortunately, KPIs for evaluation of railway ITS or their impacts are still missing [6]. Therefore, this paper identifies a set of KPIs for evaluation of railway ITS and monitoring of their impacts. The framework was not used for the identification of KPIs but only for the development of KPIs related to the evaluation of ITS. One of the most important aspects of KPIs is that 
railways can identify the best practices and take appropriate initiatives for improving technology. Without modifications, the identified KPIs could be used for evaluation of train control systems for different levels of railway network and their appropriate sub-systems. It is clear that all defined KPIs cannot be initiated/ used for evaluation of a particular railway's ITS. Which final set of KPIs will be used for evaluation and comparison of railway ITS in order to find the best practices depends on the purpose of the evaluation and on decision makers.

In terms of a literature review, a framework for identification and evaluation of the importance of KPIs for ITS does not exist. Consequently, the aim of this paper was to develop an original process for identifying and weighing a common set of KPIs for railway ITS. The framework uses a combination of the two-round Delphi technique with the GAHP method first, while SWOT analysis is applied separately. The developed framework could be used for each mode of transportation in the context of KPIs for ITS. The main contribution of this paper is twofold: (1) development, classification, and evaluation of KPIs for railway ITS, and (2) introduction of the framework for identification and assessment of KPIs for ITS.

A comprehensive literature review in terms of the application of proposed techniques regarding transport, KPIs, and ITS is presented in the next section. Section 2 presents the proposed framework through a description of steps and applied methods. Section 3 describes the results of this study, while Section 4 provides concluding remarks and proposals for future work.

\section{LITERATURE REVIEW}

In order to confirm the novelty of the framework and the combination of proposed techniques below, the literature research was focused on papers that used them in the context of rail transport, KPIs, and ITS, as well as in combination in the transport field. The search strategy consisted of a literature review of relevant studies published in peer-reviewed journals within scientific sources such as Ebsco, IEEE Xplore, ScienceDirect, Scopus, Springer, and Taylor \& Francis without any limitation on the time period of publication. The search, performed by using titles, abstracts, and keywords for English language full-text freely available scientific journal papers, was carried out in January 2017. Keywords such as "transport", "indicator", "intelligent transport system" in combination with the names of the methods "SWOT", "Group Analytical Hierarchy Process or GAHP", and "Delphi”, were combined in search strings and applied to each database. For example, SWOT and certain keywords were used, such as "SWOT AND transport", "SWOT AND indicator", "SWOT AND intelligent transport system". Besides these, combinations of different methods' names were applied - i.e., "Delphi AND SWOT", "Delphi AND Group Analytical Hierarchy Process", and "SWOT AND Group Analytical Hierarchy Process". Conference papers, projects, periodicals, and working papers related to methods used and fields of their application were not included in our review because they went through a less rigorous peer-review process. Based on the results of applied search strings, papers that applied these methods in the mentioned fields have been extracted by first reading the abstracts of the found papers, and, where relevant, the full texts.

\subsection{Application of Delphi, GAHP, and SWOT techniques}

Regarding the indicators, the Delphi technique was applied in [7] for exploring experts' views considering the changes of GDP and seven indicators which determined $\mathrm{CO} 2$ emissions of road freight in Finland. In the field of IT, Hojer [8] presented an evaluation of three different telematics scenarios for urban passengers. In terms of railway transport, Kordnejad [9] used the Delphi technique for collecting perspectives of stakeholders in the evaluation of the feasibility of rail based intermodal transportation in urban regions. Using GAHP, Shiau \& Liu [10] selected key indicators for evaluation of sustainable transport strategies. Within the GAHP method, different approaches were used for aggregating expert judgments, such as weighted arithmetic mean method [11], geometric average method [10], Kendall's rank correlation method [12,13], and a geometric average and normalization process [14]. Railway SWOT analysis was employed for considering the opening of the train route "Vilnius-Warsaw" [15], and the development of a Euro-Asian cluster of rail education and research [16]. Within the report from AECOM, SWOT was used for analyzing KPIs for ITS [17]. In the context of ITS, the reasons for considering ITS through SWOT analysis were presented by Jarašūniene [18], while Diakaki et al. [19] represented functions of a variety of vehicle automation and communication systems.

\subsection{Combination of presented techniques}

Numerous papers combined the Delphi technique and the AHP method with regard to transport. Primarily, the Delphi technique was applied as a method of identification, while AHP was applied as a method of weighing factors or criteria [20-24]. Regarding the indicators, Delbari et al. [25] applied the Delphi technique for identification, while AHP was used for determining the priority of key competitiveness indicators and drivers of full-service airlines, and for considering weights of safety performance indicators for 
monitoring the safety management process of a civil aviation unit [26]. The combination of the Delphi technique and SWOT analysis can be found in [27, 28].

One can find papers which combine this tool with the AHP method in order to overcome the disadvantages of SWOT analysis [29-31].

\section{THE PROPOSED FRAMEWORK}

In terms of our study, the framework of development and evaluation of KPIs for railway ITS is composed of the following steps, presented in Figure 1: (1) development of a comprehensive set of KPIs based on the papers related to evaluation of ITS found during the literature review and on the authors' knowledge (the initial set of KPIs was defined by the authors); (2) selection of experts for validation of developed KPIs and their classification, as well as evaluation of KPIs' importance through the Delphi technique; (3) application of GAHP for calculation consistency of returned questionnaires and weights of KPIs; (4) presentation of the strengths, weaknesses, opportunities, and threats (SWOT) analysis for the developed KPIs.

\section{Step 1: Development of indicators}

In order to evaluate railway ITS and their effects on the performance of railway transport, an appropriate set of indicators must be developed. The starting or initial set of KPls was defined by the authors based on their experience and knowledge. During the literature review, this set of KPIs was complemented by those found in the selected papers, i.e., papers that were related to the evaluation of railway ITS. As a result, twenty-five indicators for railway ITS were created. For all of them, objectives have been defined wherever possible and weights of each KPI by Delphi-GAHP have been indicated (see Table 1). Following Chowdhury's [32] recommendation that ITS should be involved always in order to "meet the needs of transport sustainability", indicators have been grouped into economic, social and environmental dimensions of sustainability with the aim of facilitating the monitoring of their contributions towards a sustainable railway. Eight indicator themes behind these dimensions are comprised of corresponding indicators integrated into the whole indicator framework structure. Indicators which do not directly describe a strong correlation with ITS, i.e., The number of trains and Weight of freight and passenger train, have been introduced because they are the main factors and sources of increased energy consumption and GHG emissions, respectively. They are necessary for the evaluation of ITS environmental impacts. Moreover, they are useful for assessing the impacts of ITS on the capacity of infrastructure due to their correlation with and impact on capacity consumption [33] (see Table 1).

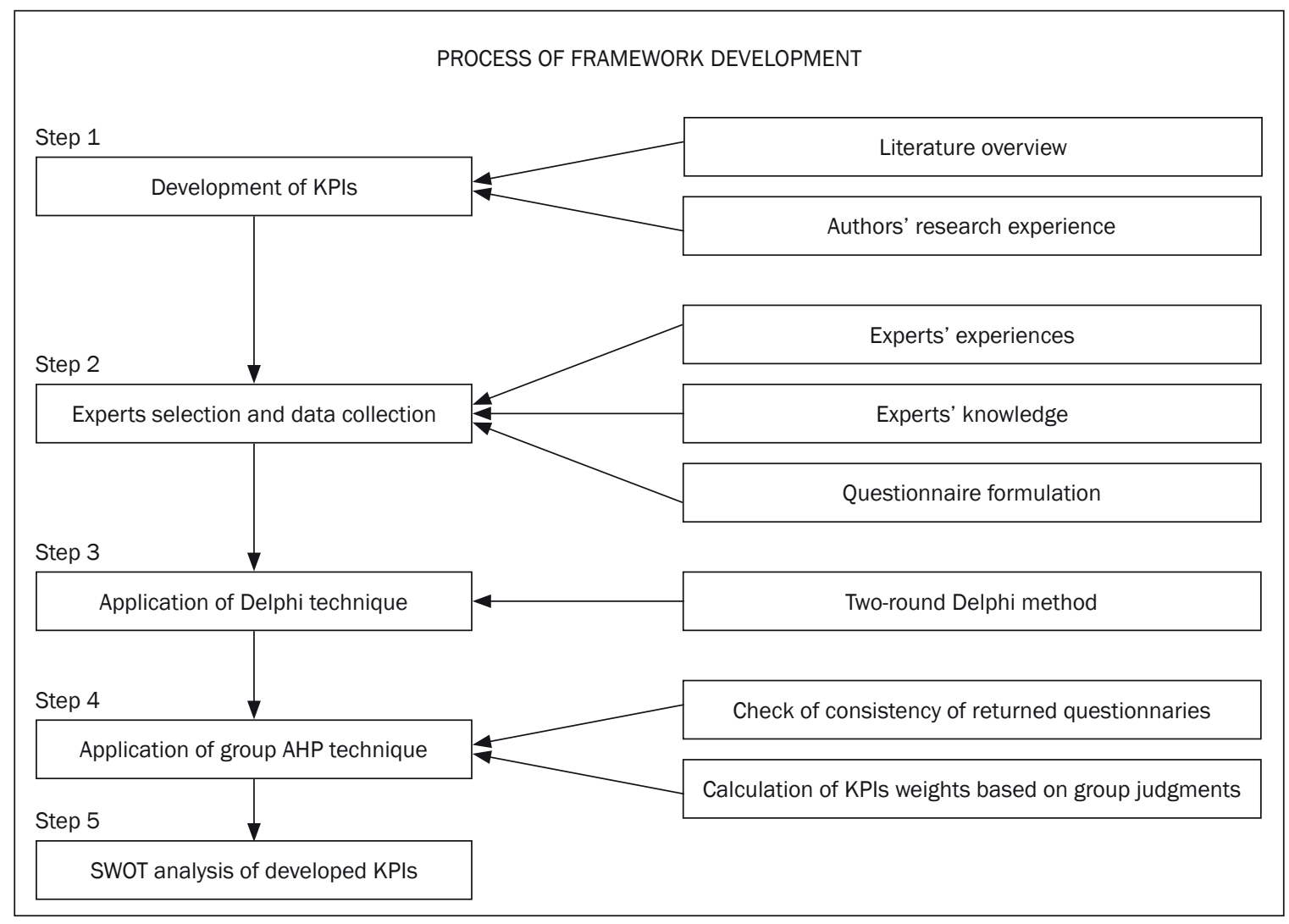

Figure 1 - Steps of the framework development process 
Table 1 - Set of KPIs for railway ITS and results of Group AHP

\begin{tabular}{|c|c|c|c|c|c|}
\hline Dimension & Themes & Indicators & Description and/or objective & $\begin{array}{l}\text { Weights } \\
\text { by GAHP }\end{array}$ & CR \\
\hline \multirow{19}{*}{ 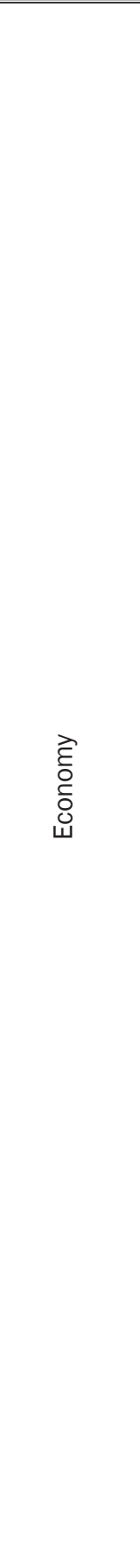 } & \multirow{5}{*}{ 雚 } & Investment costs of ITS & $\begin{array}{l}\text { Minimize total construction costs of systems and } \\
\text { equipment and its installation }\end{array}$ & 0.18812 & \multirow{5}{*}{$\begin{array}{l}\text { N } \\
\infty \\
N \\
O \\
0\end{array}$} \\
\hline & & $\begin{array}{l}\text { Operating/enforcement } \\
\text { costs of ITS }\end{array}$ & $\begin{array}{l}\text { Minimize total costs of operation/enforcement of } \\
\text { overall systems (centers and equipment). }\end{array}$ & 0.06983 & \\
\hline & & Maintenance cost of ITS & $\begin{array}{l}\text { Minimize total costs of overall systems } \\
\text { maintenance. }\end{array}$ & 0.12864 & \\
\hline & & $\begin{array}{l}\text { Operation and maintenance } \\
\text { costs of railway }\end{array}$ & $\begin{array}{l}\text { Minimize total operation cost of the railway by the } \\
\text { implementation of ITS. }\end{array}$ & 0.35877 & \\
\hline & & $\begin{array}{l}\text { The number of employed } \\
\text { in operations and traffic }\end{array}$ & $\begin{array}{l}\text { Minimize the total number of employees in } \\
\text { operating and organizing traffic. }\end{array}$ & 0.25463 & \\
\hline & \multirow{7}{*}{ 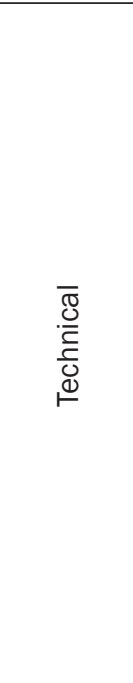 } & $\begin{array}{l}\text { The total kilometers of rail } \\
\text { with ITS }\end{array}$ & $\begin{array}{l}\text { Maximize length of rail or number of kilometers of } \\
\text { rail covered with ITS (traffic management systems, } \\
\text { train control systems). }\end{array}$ & 0.35444 & \multirow{7}{*}{ 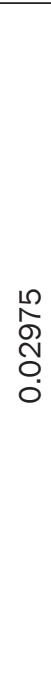 } \\
\hline & & The number of trains & $\begin{array}{l}\text { A total number of electrical and diesel locomotives, } \\
\text { which are in working order. }\end{array}$ & 0.0248 & \\
\hline & & The number of tracks & Single-track or double-track railway. & 0.09327 & \\
\hline & & $\begin{array}{l}\text { The number of level } \\
\text { crossings }\end{array}$ & $\begin{array}{l}\text { Minimize the total number of crossings, including } \\
\text { active and passive systems, as a black point. }\end{array}$ & 0.09928 & \\
\hline & & $\begin{array}{l}\text { The number of } \\
\text { interlocking systems }\end{array}$ & $\begin{array}{l}\text { A total number of interlocking systems, which } \\
\text { represent a signaling subsystem. }\end{array}$ & 0.14995 & \\
\hline & & $\begin{array}{l}\text { The number of control } \\
\text { centers }\end{array}$ & $\begin{array}{l}\text { A total number of control centers (local, national) } \\
\text { for regulating train traffic. }\end{array}$ & 0.0931 & \\
\hline & & System failures & $\begin{array}{l}\text { Minimize the number of failures on site (signals, } \\
\text { level crossings, points, axle counters, and circuit } \\
\text { failures) or on the entire system, including human } \\
\text { factors which cause delays }>10 \text { minutes. }\end{array}$ & 0.18517 & \\
\hline & \multirow{7}{*}{ 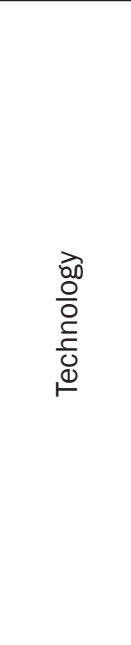 } & Commercial speed of train & $\begin{array}{l}\text { Maximize speed on routes where ITS has been } \\
\text { implemented. }\end{array}$ & 0.09433 & \multirow{7}{*}{$\begin{array}{l}1 \\
\infty \\
0 \\
0 \\
0 \\
0\end{array}$} \\
\hline & & $\begin{array}{l}\text { Weight of freight and } \\
\text { passenger trains }\end{array}$ & $\begin{array}{l}\text { Maximize average allowed weight of train in } \\
\text { accordance with axle load category. }\end{array}$ & 0.09577 & \\
\hline & & Average length of train & $\begin{array}{l}\text { Maximization of the average length of the train due } \\
\text { to the introduction of moving blocks. }\end{array}$ & 0.06775 & \\
\hline & & $\begin{array}{l}\text { Reduction of time } \\
\text { windows }\end{array}$ & Minimize time windows for maintenance routes. & 0.10138 & \\
\hline & & $\begin{array}{l}\text { Average headway } \\
\text { between trains }\end{array}$ & $\begin{array}{l}\text { Minimize average headway between trains after } \\
\text { ITS implementation. }\end{array}$ & 0.21586 & \\
\hline & & $\begin{array}{l}\text { Turnover locomotives } \\
\text { and sets }\end{array}$ & $\begin{array}{l}\text { Minimize time of the overall turnover locomotives } \\
\text { and sets. }\end{array}$ & 0.11596 & \\
\hline & & Traffic volume & $\begin{array}{l}\text { Maximize realized (passenger, freight, train) } \\
\text { kilometers along routes where ITS have been } \\
\text { implemented. }\end{array}$ & 0.30896 & \\
\hline \multirow{4}{*}{$\begin{array}{l}\overrightarrow{0} \\
\frac{0}{0} \\
\dot{0}\end{array}$} & $\stackrel{\nexists}{\stackrel{\nexists}{\beth}}$ & Travel time & $\begin{array}{l}\text { Minimize travel time for a trip from one site to } \\
\text { another on the rail after ITS implementation. }\end{array}$ & 0.39692 & \multirow{4}{*}{ 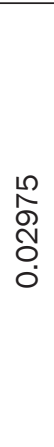 } \\
\hline & $\overrightarrow{0}$ & Frequency of trains & $\begin{array}{l}\text { Maximize the number of trains frequency on the } \\
\text { track after ITS implementation }\end{array}$ & 0.10136 & \\
\hline & 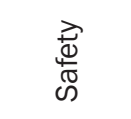 & Number of accidents & $\begin{array}{l}\text { Minimize the number of accidents on routes with } \\
\text { ITS (including level crossings, train collisions, } \\
\text { derailments). }\end{array}$ & 0.20918 & \\
\hline & 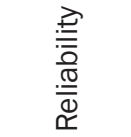 & Average delay of train(s) & Minimize delay on rail with ITS. & 0.29254 & \\
\hline
\end{tabular}




\begin{tabular}{|c|c|c|c|c|c|}
\hline Dimension & Themes & Indicators & Description and/or objective & $\begin{array}{l}\text { Weights } \\
\text { by GAHP }\end{array}$ & CR \\
\hline \multirow{2}{*}{ 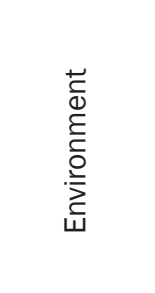 } & 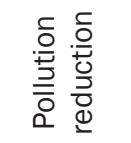 & Amount of GHG emissions & $\begin{array}{l}\text { Minimize annual GHG emissions on the rail with } \\
\text { ITS. }\end{array}$ & 0.47847 & \multirow{2}{*}{ 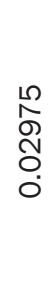 } \\
\hline & 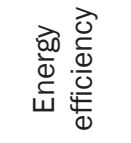 & Energy consumption & Minimize energy consumption on the rail with ITS. & 0.52153 & \\
\hline
\end{tabular}

Indicators which are included in this economic dimension refer to costs of investment, maintenance, and operation of ITS technologies. These indicators represent direct costs of ITS implementation. The indicators Costs of operation and maintenance of railway and The number of employed in operations indirectly reflect the change of the costs due to ITS implementation. Operation and maintenance costs of the railway may be reduced by introducing automated track maintenance technology [34]. For example, the implementation of the European Railway Traffic Management System (ERTMS) implies dramatically lower maintenance costs [35]. The number of employed in operations and traffic may be reduced by introducing remote controlled safety devices. The inclusion of this indicator helps understanding ITS efficiency in terms of the number of employees and is thus included in this dimension [36]. The number of tracks, as the most important feature of railway infrastructure, Time windows for maintenance, and Average headway between trains contribute to the increase of rail capacity [37]. With ITS, The total kilometers of rail with ITS increases the efficiency of track utilization which results in a linear increase of revenues, as well as costs of reconstruction and maintenance [34].

Additionally, one of the most relevant efficiency indicators that the economy of railway depends on is Traffic volume, i.e., the number of passenger or freight kilometers. High utilization of railway assets, such as the number of trains, leads to more efficient railways. Moreover, network complexity, i.e., certain network characteristics such as the number of level crossings, the number of interlocking systems, the number of control centers, which are elements of railway signaling, have crucial influence on capacity and long-term impacts on infrastructure maintenance costs [37]. The indicator which refers to failures of the system has been introduced as it has potentially significant consequences for the economy [38]. Additionally, the implementation of ITS may have a significant influence on the increase of commercial speed of train, turnover locomotives and assets, and the average length of the train, which has a positive impact on revenue and capacity consumption. Therefore, they are included in this dimension. As tracks that can handle heavier loads have contributed to reduced costs of freight rail- ways and improved transport capacity, the indicator Weight of freight and passenger trains has been included in the economy dimension [37, 39].

To meet the needs of society, aside from its dominant function - transportation of goods and people - transport should fulfill several additional functions [36]. Even though rail transport is treated as a safer mode of transportation, the indicator Number of accidents has been introduced, as railway accidents may occur due to a system error. Moreover, there are many accidents caused by lack of safety awareness from railway workers and the public, such as crossing accidents [40]. A reliable railway is the most important requirement of railway customers [41]. Further, an indicator such as Average delay of the train(s) is important due to the reduction or termination of the functional performance of the infrastructure [38]. Therefore, the indicator Average delay of the train(s) has been introduced because it is expected that adequate use and implementation of ITS shall increase reliability [37]. Additionally, mobility measures should reflect the ability of people and goods to reach different destinations and is mainly concerned with travel time [42]. Travel time and frequency of trains may be favorable indicators which point to mobility changes.

The challenge of climate change and the depletion of natural resources are indispensable elements of any sustainable strategy. Rail transport requires low energy usage and emits fewer air pollutants than other modes [41]. ITS can help further reduce negative environmental impacts through the optimization of journeys, speed regulation, decreasing stops, delays, and accidents, as well as through improving the performance of locomotives and drivers [33, 43]. Impacts of locomotives and drivers on energy consumption and the environment can be reduced through energy-efficient driving [42]. For instance, it has been estimated that ERTMS can contribute to eco-driving support through better information [35]. Based on these, the indicators within the environment dimension are the Amount of GHG emissions and Energy consumption.

\section{Step 2: Experts selection and data collection}

In terms of qualitative evaluation, the first step before the application of the Delphi technique is, just like with the GAHP method, selecting experts. The next step is the formulation of questions for conducting 
a questionnaire [45]. Having in mind the Delphi and GAHP methodologies, the selection of experts for this paper is based on significant experience and knowledge in terms of ITS in general and railway ITS and their effects, all with the aim of validating and weighing KPIs. At the beginning, due to agreements in the literature regarding the sufficient number of experts in group decision making (GDM) within the Delphi technique [46] and the GAHP method, fifteen experts from universities and the transport industry had been invited to take part in the questionnaire. After the first round of the Delphi technique, 12 experts managed to return questionnaires. Moreover, after the second round of the Delphi process, the experts managed to achieve consistency in their judgments.

\section{Step 3: Application of Delphi technique}

The Delphi technique used as a systematic collection of the opinions of experts in a particular field [47] could also be an effective tool in case of a need to deal with complex problems, the GDM process, incomplete and unavailable data. Based on the ability to combine and refine the opinions of a group of experts through the iterative process within an anonymous questionnaire, the Delphi process is repeated and completed until a collective judgment, the consensus of expert opinions in terms of consistency of returned questionnaires, is achieved [48]. A smaller group, which consists of 8 to 12 experts, is more realistic and desirable for the application of the Delphi process [46].

The two-round Delphi method was selected for this study due to its ability to efficiently and effectively summarize the opinions of experts. In our paper, the Delphi technique is used as a platform for validation of development, classification of KPIs, and weighting KPIs through the opinions of selected experts. The questionnaires have been distributed via mail to respondents in order to reduce time to collect answers. In the first round, participants were asked to review the developed and classified KPIs. The second round was based on expert judgments for each KPI in terms of their importance in the evaluation of railway ITS and their effects.

\section{Step 4: Weighing KPIs by Group Analytical Hierarchy Process}

The Analytical Hierarchical Process (AHP) is an effective tool introduced by [49] for dealing with the complex problem that is broken down into hierarchically smaller constituents, from goals, criteria, and sub-criteria to alternatives at the bottom level of the hierarchy. The AHP method is based on pairwise comparisons between decision elements with the purpose of obtaining their weights of importance [50], both through qualitative and quantitative data and single and multi-dimensional cases [52]. Since the decision-making process involves several decision makers (DMs), standard AHP has been adjusted in GDM, simultaneously avoiding the bias of individual DMs [54]. This paper uses the GAHP technique for measuring the importance of each KPI. Through measuring the importance of KPIs, the most significant KPIs can be identified. The GAHP technique was selected because of its potential when combined with DMs judgments. In addition, using matrices of pairwise comparisons within AHP, indicator performances can be determined. KPI weights were calculated with the "ExpertChoice" software, designed for AHP through comparisons of KPIs in pairwise matrices based on DMs judgments quantified using the 9-point Saaty scale. Within the economic dimension, each theme represents a matrix of KPI comparisons, while the other two dimensions represent matrices of comparisons due to a lower number of KPIs. The upper triangular cells in the matrix are filled by DMs, while the lower triangular cells in the matrix represent reciprocal judgment values. If a matrix is completely consistent, weights can be obtained through the formula $A w=\lambda_{\max } w$, where $A$ is comparison matrix, $\lambda_{\text {max }}$ pricipal eigenvalue, and $w$ is a vector of the priorities, whereby $\sum w_{i}=1$ for each matrix. Since DMs act like one single individual in our paper, a synergistic AIJ with a geometric mean method $A_{i j}^{\prime}=\prod_{k=1}^{m}\left(a_{i j}^{(k)}\right)^{\lambda_{k}}$, where $i, j=1,2 \ldots, n$ and $k=1,2, \ldots, m$ and $i \neq j$, , is used for obtaining group judgment, i.e., the main matrix of comparison by matrices of each respondent [53,54], where $i$ and $j$ represent compared $\mathrm{KPI}, k$ is number of $\mathrm{DM}$, and $\lambda_{k}$ is weight for each DM.

In order to obtain a more realistic importance of KPIs, the authors assigned the same weight for each $\mathrm{DM}$, hence $\lambda_{k}=0.08$. The next step and an important part of the GAHP methodology is checking the consistency ratio (CR) of pairwise matrices. Firstly, the consistency index $(\mathrm{Cl})$ is calculated as $C I=\frac{\left(\lambda_{\max }-n\right)}{(n-1)}$. .Consistency ratio (CR) is defined as $\mathrm{Cl}$ divided by random index $(\mathrm{RI})$, where $\mathrm{RI}$ is calculated from the average $\mathrm{Cl}$ of 1,000 random samples. Consistency is checked for each returned questionnaire, and if the value of consistency ratio is below 0.1 , the decision makers' judgments are considered consistent, after which the main matrices are created (CR values for each theme are shown in the column CR of Table 1 ).

\section{Step 5: Analyzing KPls by means of SWOT analysis}

The primary goal of SWOT analysis is an evaluation of internal (strengths and weaknesses) and external (opportunities and threats) environments in a process in order to attain a systematic approach and support for a decision situation [30]. In our study, it has been used to analyze the strengths, weaknesses, opportunities, and threats of KPIs for railway ITS. For that purpose, the matrices have been used to distinguish internal factors from external factors that could have a positive or negative impact on evaluating 
Table 2 - Internal factors of developed KPIs

\begin{tabular}{||l|l||}
\hline \multicolumn{2}{|c||}{ Strengths } \\
\hline \multicolumn{2}{|c||}{ Internal factors } \\
\hline \hline - Offer knowledge and understanding of effects of ITS & - Possibility of lesser quality and unavailability of data. \\
towards a sustainable railway. & - Insufficient development of each system in synergy. \\
- Consider the benefits from other points of view, not only & - When considering a complex ITS like train control system, \\
from the economic one. & collection of a large set of data is required. \\
- Create the normative basis for improvement of railway & - Requirements for additional data and associated costs. \\
performance by ITS. & - Collection of data for a longer period or before and after \\
- Provide useful information for all kinds of stakeholders. & implementation of systems needed. \\
- Enable comparable data for monitoring enhancements & - Data for some level of monitoring may only be inferred \\
on sustainable railway. & from others indicators (the case with GHG emissions). \\
- Applicable for all approaches to evaluation. & - Some KPIs may require qualitative data. \\
- Usable for railway network as a whole or only for an & \\
appropriate part. & \\
- Represent all factors that can have relations with the & \\
application of ITS. & \\
\hline
\end{tabular}

Table 3 - External factors of developed KPIs

\begin{tabular}{|c|c|}
\hline \multicolumn{2}{|c|}{ External factors } \\
\hline Opportunities & Threats \\
\hline \begin{tabular}{|l} 
- KPIs could be expanded to different ITS and comparable \\
for each railway. \\
- Easier research and assessment of ITS impacts. \\
- Better information, data, and results sharing. \\
- Applicable for each country or railway company. \\
- Higher involvement of policy makers in improvements of \\
investments in railway ITS.
\end{tabular} & $\begin{array}{l}\text { - Limitation of railway sector regarding data availability. } \\
\text { - The necessity of consideration of some additional } \\
\text { influence factors with KPIs in ITS evaluation. } \\
\text { - The presence of different data sources for KPIs. } \\
\text { - The requirement of interaction with different railway } \\
\text { operators. } \\
\text { - Reduction of further adjustment of KPIs. } \\
\text { - Unequal application of KPIs. } \\
\text { - Lack or decreased support from stakeholders. }\end{array}$ \\
\hline
\end{tabular}

railway ITS and measuring their impacts with developed KPIs. The strengths and weaknesses, as well as opportunities and threats of the KPIs for railway ITS, are presented in Table 2 and Table 3.

\section{RESULTS OF THE FRAMEWORK}

The developed KPIs were reviewed by twelve experts, seven of which were scholars in the field of rail transport and railway ITS, three experts in the area of transport, and two in the field of ITS. All of them were contacted by mail, firstly for checking the developed KPIs and their classification. After the first Delphi round, only one indicator, Turnover locomotives and sets, was added, and some corrections regarding the names of KPIs were made. Then, within the second round of the Delphi technique, the experts assessed the KPIs' importance by comparing indicators. The final importance of each KPI was calculated by means of the GAHP method. It should be noted that after the aggregation of the individual rates with the geometric mean method, the results had a decimal value, and the authors circled the first largest value in group decision comparison matrices. The results of the GAHP are presented in the column Weights by GAHP of Table 1.
With the GAHP based on the experts' opinions, the final set of KPIs required for the evaluation of a particular railway ITS can be determined, because it is impossible to use all defined KPIs in all cases. Based on the results of the GAHP using experts' judgements, the final set of the most important indicators was therefore created. In addition, the importance of other indicators was determined. The most important KPIs for evaluation of railway ITS within the cost theme is Operation and maintenance costs of the railway (weight of $\mathrm{GAHP}=0.35877$ ), while the least important is Operating/enforcement costs of ITS (0.06983). The total kilometers of rail with ITS is the most important in the technical theme (0.35444), and the one with the lowest value based on the experts' opinions is The number of trains (0.0248). This is obvious because The number of trains is not directly connected with ITS. On the other hand, The number of trains is linked to railway capacity, which significantly depends on ITS. Moreover, one of the main disadvantages of the ERTMS was precisely the number of trains that can be serviced. Within the technological theme, the first ranked is Traffic volume (0.30896), while the least important indicator is the Average length of the train (0.06775). Even though The number of trains and Average length of the train have no direct link with the application of 
ITS, they can significantly impact railway capacity and cause ITS inefficiency. In terms of evaluation of railway ITS and monitoring impacts on society dimensions, the most significant is Travel time (0.39692), while the least important is the Frequency of trains (0.10136). Similar to The number of trains, Frequency of trains can be a good indicator when representing the ERTMS functioning, despite its low importance. In the end, between the two indicators in the environmental dimension, Energy consumption (0.52153) is the most important in the assessment of railway ITS effects, according to the respondents.

Table 2 illustrates the strengths and weaknesses, while Table 3 presents the opportunities and threats of the developed KPIs for railway ITS evaluation. The presented dimensions, themes, and the related set of KPIs provide a framework for knowledge and understanding of the contributions of railway ITS towards sustainable railway. Through providing a normative basis for improvement of railway performance, KPIs could be treated as decision-making instruments. A new way of providing and comparing information for stakeholders is achieved by means of the developed KPIs. The presented set of indicators could be applied to the entire network, part of the network or a specific rail section, as well as to various approaches or methods of evaluation. However, disadvantages of KPIs refer to the lack of a unique source of data that can influence its quality. Data for some of the presented indicators could be collected from a statistical database such as Eurostat, while data for some other indicators could be obtained only from the authorities, managers, operators, the Ministry, etc. Some of the developed KPIs can be interpreted only in terms of experts' opinions, while some of them could be drawn from others sources and require additional data.

The developed KPIs could provide communication channels between different railways and countries, as well as help identify the best practices in railway ITS implementation. These indicators may enhance research and assessment of ITS effects/impacts. Awareness of policy makers in terms of ITS implementation could be improved through KPIs. Significant threats related to the use of KPIs are the unavailability of data, a different source of data with different means of collection, unequal interpretation of KPIs across railway sectors, interaction with operators that prevent data acquisition.

\section{CONCLUSION}

The main contribution of this paper is twofold: (1) development, classification, and evaluation of KPIs for railway ITS, and (2) identification and evaluation of indicators for assessing railway ITS and their impacts using the Delphi and GAHP techniques. Moreover, the developed framework could be applied for identification and evaluation of KPIs for ITS of other transport modes. The developed framework was not used for the KPIs identification because KPIs were mostly identified from studies related to ITS evaluation. In order to avoid the partiality of individual respondents, aggregation of individual grades into a group grade for each indicator was necessary. In this way, a realistic image of the significance of indicators for evaluating railway ITS was obtained. In such circumstances, indicator valuation based on the GAHP method provides useful information. As for group evaluation of indicators by the AHP method, the analysis has determined the most important indicators for evaluating railway ITS. Hence, the main target measured with GAHP was the importance of KPIs. Since the application of all KPIs in the evaluation of an ITS cannot provide adequate results about that particular ITS, the initial final set of KPIs can be defined using group AHP. In addition, using the pairwise comparisons matrices of AHP, KPI performance can be measured. This paper has also used SWOT analysis for considering strengths, weaknesses, opportunities, and threats regarding the developed KPIs. The developed indicators for evaluating railway ITS enable making comparative performance assessment of existing ITS operations, conducting ITS gap analysis, and developing performance-based investment plans that lead to effective ITS deployment decisions. However, it is important to have in mind that indicators display mutual dependence during their development for ITS evaluation. For instance, reduction of train delays has an impact on capacity increase, etc. Therefore, future work will be focused on the application of Fuzzy Cognitive Maps (FCM) and DEMATEL tools for constructing a mutual connection between different indicators for evaluating railway ITS. As far as limitations are concerned, the authors highlight the efficacy of the application of the SWOT analysis to KPIs.

Prof. dr. SC. TOMISLAV JOSIP MLINARIĆ ${ }^{1}$

E-mail: tmlinaric@fpz.hr

BOBAN ĐORĐEVIĆ, Ph.D. student ${ }^{2}$

E-mail: bbn.djordjevic@gmail.com

Doc. dr. sc. EVELIN KRMAC ${ }^{2}$

E-mail: evelin.krmac@fpp.uni-lj.si

${ }^{1}$ Fakultet prometnih znanosti, Sveučilište u Zagrebu

Vukelićeva 4, 10000 Zagreb, Hrvatska

2 Fakulteta za pomorstvo in promet, Univerza v Ljubljani

Pot pomorščakov 4, SI-6320 Portorož, Slovenija

OKVIR ZA EVALUACIJU KLUUČNIH POKAZATELJA UČINKOVITOSTI ŽELJEZNIČKIH ITS SUSTAVA

\section{SAŽETAK}

Cilj ovog rada je razviti okvir za istraživanje cjelovitog skupa pokazatelja ključnih učinaka (KPI) za procjenu željezničkih inteligentnih transportnih sustava (ITS). Okvir je 
uspostavljen kroz četiri glavna koraka: (1) razvoj sveobuhvatnog skupa KPIs za željeznički ITS; (2) potvrđivanje razvijenih KPI i prikupljanje ocjena od stručnjaka putem Delphi upitnika; (3) evaluacija značaja KPI-a za procjenu željezničkog ITS-a pomoću grupnoga procesa analitičke hijerarhije (GAHP); i (4) predstavljanje rezultata SWOT analize za razvijene KPl-e. Rezultati okvira prikazani su kao skup od 25 pokazatelja za procjenu željezničkog ITS-a i njihovih utjecaja. Okvir bi mogao biti koristan za odabir KPIs ITS-a i u nekom drugom podsustavu prijevoza. Praćenje doprinosa ITS-a prema održivoj željezničkoj infrastrukturi može se postići razvijenim skupom pokazatelja koji su klasificirani u skladu s održivim dimenzijama.

\section{KLUUČNE RIJEČI}

okvir; željeznički transport; inteligentni transportni sustavi; grupno odlučivanje; identifikacija; procjena, održiva željeznica;

\section{REFERENCES}

[1] Fantechi A, Flammini F, Gnesi S. Formal methods for railway control systems. International Journal on Software Tools for Technology Transfer. 2014;16: 643-646.

[2] Ning B, Tang T, Yan F, Wang F-Y, Zeng D. Intelligent Railway Systems in China. IEEE Intelligent Systems. 2006;21(5): 80-83.

[3] Zhicai J, Jianping W, McDonald M. Socio-Economic Impact Assessment of Intelligent Transport Systems. Tsinghua Science and Technology. 2006;11(3): 339-350.

[4] European Commission. Communication from the Commission - Action Plan for the Deployment of Intelligent Transport Systems in Europe. Brussels; 2008. Available from: http://eur-lex.europa.eu/legal-content/EN/ TXT/PDF/?uri=CELEX:52008DC0886 \&from=EN

[5] European Union Parliament. DIRECTIVE 2010/40/EU of the European Parliament and of the Council of the European Union of 7 July 2010 on the framework for the deployment of Intelligent Transport Systems in the field of road transport and for interfaces with other modes of transport; 2010. Available from: http://eurlex.europa.eu/legal-content/EN/TXT/PDF/?uri=CELEX:32010L0040\&from=EN

[6] Djordjevic B, Krmac E. Key Performance Indicators for Measuring the Impacts of ITS on transport. International Symposium on Electronics in Transport - ISEP 2016; Ljubljana, Slovenija; 2016.

[7] Liimatainen H, Kallionpää E, Pöllänen M, Stenholm P, Tapio P, McKinnon A. Decarbonizing road freight in the future - Detailed scenarios of the carbon emissions of Finnish road freight transport in 2030 using a Delphi method approach. Technological Forecasting \& Social Change. 2014;81: 177-191.

[8] Hojer M. Transport telematics in urban systems - A backcasting Delphi study. Transportation Research Part D. 1998;3(6): 445-463.

[9] Kordnejad B. Stakeholder analysis in intermodal urban freight transport. Transportation Research Procedia. 2016;12: 750-764.

[10] Shiau T-A, Liu J-S. Developing an indicator system for local governments to evaluate transport sustainability strategies. Ecological Indicators. 2013;34: 361-371.

[11] Yedla S, Shrestha MR. Multi-criteria approach for the selection of alternative options for environmentally sustainable transport system in Delhi. Transportation Research Part A: Policy and Practice. 2003;37(8): 717-729.

[12] Podvezko V, Sivilevičius $\mathrm{H}$. The use of AHP and rank correlation methods for determining the significance of the interaction between the elements of a transport system having a strong influence on traffic safety. Transport. 2013;28(4): 389-403.

[13] Jakimavicius M, Burinskiene M, Gusaroviene M, Podviezko A. Assessing multiple criteria for rapid bus routes in the public transport system in Vilnius. Public Transport. 2016;8: 365-385.

[14] Shiau T-A. Evaluating sustainable transport strategies for the counties of Taiwan based on their degree of urbanisation. Transport Policy. 2013;30: 101-108.

[15] Butkevičius J. Development of Passenger Transportation by Railroad from Lithuania to European States. Transport. 2007;12(2): 73-79.

[16] Tsykhmistro S, Cheptsov M, Cheklov V, Marinov M. Euro-Asian Co-operation in Rail Education and Research. Transport Problems. 2014;9(1): 103-110.

[17] AECOM. Key Performance Indicators for Intelligent Transportation Systems. Bristol: European Commission; 2015. Available from: http://ec.europa.eu/ transport/sites/transport/files/themes/its/studies/ doc/its-kpi-final_report_v7_4.pdf.

[18] Jarašūniene A. Analysis of possibilities and proposals of intelligent transport system (ITS) implementation in Lithuania. Transport. 2006;21(4): 245-251.

[19] Diakaki C, Papageorgiou M, Papamichail I, Nikolos I. Overview and analysis of Vehicle Automation and Communication Systems from a motorway traffic management perspective. Transportation Research Part A. 2015;75: 147-165.

[20] Tsai M-C, Su C-H. Political risk assessment of five East Asian ports - the view points of global carriers. Marine Policy. 2005;29: 291-298.

[21] Lee BC, Wan J, Shi W, Li K. A cross-country study of competitiveness of the shipping industry. Transport Policy. 2014;35: 366-376.

[22] Emovon I, Norman RA, Murphy AJ. Hybrid MCDM based methodology for selecting the optimum maintenance strategy for ship machinery systems. J Intell Manuf; 2015. doi:10.1007/s10845-015-1133-6

[23] Curiel-Esparza J, Mazario-Diez JL, Canto-Perello J, Martin-Utrillas M. Prioritization by consensus of enhancements for sustainable mobility in urban areas. Environmental Science \& Policy. 2016;55: 248-257.

[24] Hruška R, Průša P, Babić D. The use of AHP method for selection of supplier. Transport. 2014;29(2): 195-203. doi:10.3846/16484142.2014.930928

[25] Delbari SA, Ng SI, Aziz YA, Ho JA. An investigation of key competitiveness indicators and drivers of full-service airlines using Delphi and AHP techniques. Journal of Air Transport Management. 2016;52: 23-34.

[26] Chen W, Li J. Safety performance monitoring and measurement of civil aviation unit. Journal of Air Transport Management. 2016;57: 228-233.

[27] Párraga MM, Gonzalez-Cancelas N, Soler-Flores F. DELPHI-SWOT tools used in strategic planning of the Port of Manta. Procedia - Social and Behavioral Sciences. 2014;162: 129-138. 
[28] Hafeznia MR, Pirdashti H, Ahmadipour Z. An expert-based decision making tool for enhancing the consensus on Caspian Sea legal regime. Journal of Eurasian Studies. 2016;7: 181-194.

[29] Dimić S, Pamučar D, Ljubojević S, Đorović B. Strategic Transport Management Models-The Case Study of an Oil Industry. Sustainability. 2016;8(9): 954. doi:10.3390/su8090954

[30] Pamučar D, Ćirović G, Sekulović D. Development of an Integrated Transport System in Distribution Centers: A FA'WOT analysis. Tehnički vjesnik. 2015;22(3): 649-658.

[31] Wan C, Yan X, Zhang D, Shi J, Fu S, Ng AK. Emerging LNG-fueled ships in the Chinese shipping industry: a hybrid analysis on its prospects. WMU J Marit Affairs. 2015;14: 43-59. doi:10.1007/s13437-015-0080-6

[32] Chowdhury M. Editorial: $15^{\text {th }}$ Intelligent Transportation Systems World Congress. Journal of Intelligent Transportation Systems. 2010;14(2): 51-53.

[33] Mahmod M, Jonkers E, Klunder GA, Benz T, Winder A. Amitran methodology framework for evaluating the impact of information and communication technology-based measures on $\mathrm{CO} 2$ emissions in the transport field. IET Intelligent Transport Systems. 2015;9(4): 418-428.

[34] Jiménez-Redondo N, Escriba Marín S, García Benítez F, Cáceres N. Automated and cost effective railway infrastructure maintenance. ACEM-Rail; 2013.

[35] Psaraki-Kalouptsidi V, Pagoni I, Fröidh O. Transport Infrastructure Capacity Assessment - Rail Transport. National Technical University of Athens, Royal Institute of Technology. Deliverable D6.3 (WP 5 report), 2011. doi:0000-0002-3687-7758

[36] Mitwallyova $H$, Jankovic V. The influence of railway infrastructure on the live in selected European countries. International Journal of Business and Management. 2015;3(2): 18-26.

[37] Lindfeldt A. Railway capacity analysis: Methods for simulation and evaluation of timetables, delays and infrastructure. Stockholm: KTH Royal Institute of Technology; 2015.

[38] Famurewa SM, Stenstrom C, Asplund M, Galar D, Kumar U. Composite indicator for railway infrastructure management. J. Mod. Transport. 2014;22(4): 214-224.

[39] Sameni MK. Railway Track Capacity: Measuring and Managing. University of Southampton, Faculty of Engineering and the Environment; 2012.

[40] Song B-Y, Moon D-S, Lee HS. Development of the Assessment Indicators for Railway Safety. International Journal of Railway. 2012;5(4): 175-181.
[41] Ahrens J, Dogs J, Kupke D, Sagevik M. UIC reporting guideline sustainable mobility and transport: Reporting Principles and Indicators for Rail. UIC International Union of Railways; 2011.

[42] Kaparias I, Bell GM. Key Performance Indicators for traffic management and Intelligent Transport Systems. CONDUITS, Coordination of Network Descriptors for Urban Intelligent Transport Systems; 2011.

[43] Canaud M, El Faouzi N-E. ECOSTAND: towards a standard methodology for environmental evaluation of ITS. Transportation Research Procedia. 2015;6: 377-390.

[44] Haramina H, Mandić M, Nikšić, M. New method for energy-efficient train operation on commuter rail networks. Technical Gazette. 2012;19(4): 801-806.

[45] Piecyk MI, McKinnon AC. Forecasting the carbon footprint of road freight transport in 2020. International Journal of Production Economics. 2010;128: 31-42.

[46] Still BG, May AD, Bristow AL. The assessment of transport impacts on land use: practical uses in strategic planning. Transport Policy. 1999;6: 83-98.

[47] Mason KJ, Alamdari F. EU network carriers, low cost carriers and consumer behaviour: A Delphi study of future trends. Journal of Air Transport Management. 2007;13: 299-310.

[48] Cafiso S, Graziano AD, Pappalardo G. Using the Delphi method to evaluate opinions of public transport managers on bus safety. Safety Science. 2013;57: 254-263.

[49] Saaty TL. The Analytic Hierarchy Process. McGraw-Hill; 1980.

[50] Srdjevic B, Srdjevic Z, Blagojevic B, Suvocarev K. A twophase algorithm for consensus building in AHP-group decision making. Applied Mathematical Modelling. 2013;37: 6670-6682.

[51] AlSabbagh M, Siu YL, Guehnemann A, Barrett J. Integrated approach to the assessment of $\mathrm{CO} 2 \mathrm{e}$-mitigation measures for the road passenger transport sector in Bahrain. Renewable and Sustainable Energy Reviews. 2017;71: 203-215.

[52] Ishizaka A, Labib A. Selection of new production facilities with the Group Analytic Hierarchy Process Ordering method. Expert Systems with Applications. 2011;38: 7317-7325.

[53] Forman E, Peniwati K. Aggregating individual judgments and priorities with the analytic hierarchy process. European Journal of Operational Research. 1998;108: 165-169.

[54] Ossadnik W, Schinke S, Kaspar RH. Group Aggregation Techniques for Analytic Hierarchy Process and Analytic Network Process: A Comparative Analysis. Group Decis Negot. 2016;25(2): 421-457. 